\title{
Cardiovascular response during severe acute asthma and its treatment in children
}

\author{
AT EDMUNDS, S GODFREY
}

From the Department of Paediatrics and Neonatal Medicine, Hammersmith Hospital, London

\begin{abstract}
Heart rate, blood pressure, pulsus paradoxus, and cardiac output measured by means of transthoracic electrical impedance cardiography have been recorded in 29 children mean age 10 years $\pm 2 \mathrm{SD}$ during status asthmaticus. Changes were recorded over the first two hours of treatment during which all patients received oxygen, intravenous fluid, and hydrocortisone, and were randomly assigned to receive aminophylline, salbutamol, or both. Admission values showed significant correlation of pulsus paradoxus with $\mathrm{PaCO}_{2}(\mathrm{r}=0.66)$. Pulsus paradoxus was greater than $20 \mathrm{mmHg}$ for all patients with $\mathrm{PaCO}_{2}$ above $5.5 \mathrm{kPa}$. Mean stroke volume and cardiac output were $89 \%$ and $131 \%$ of the resting convalescent values in the same children. Stroke volume cardiac output and heart rate did not correlate with peak expiratory flow rate or blood gas measurements. Aminophylline and salbutamol together were associated with significantly greater increase in PEF than aminophylline alone $(\mathrm{p}<0.05)$. Nebulised salbutamol was just as effective as intravenous salbutamol. Heart rate and systolic blood pressure declined significantly after nebulised salbutamol and aminophylline, but not after intravenous salbutamol and aminophylline. Stroke volume and cardiac output did not change significantly in any treatment group.
\end{abstract}

The disturbance of ventilatory function during severe acute asthma is associated with significant cardiovascular responses. Sinus tachycardia is almost always found, ${ }^{1-4}$ though correlation with severity of illness is poor. ${ }^{14}$ Pulsus paradoxus increases with severity of asthma, ${ }^{3-7}$ reflecting a fall of pulse pressure and perhaps of stroke volume during inspiration. Permutt ${ }^{8}$ reported increased cardiac output in two adult volunteers during moderately severe asthma induced in the laboratory. There are no reports of the changes of cardiac output in children during severe asthma, but the finding of metabolic acidosis ${ }^{1}$ suggests that oxygen supply to tissues may be inadequate. Arterial hypoxaemia which occurs frequently ${ }^{1-4}$ may account for the tissue hypoxia. Its effect would be compounded if cardiac output and tissue perfusion were reduced. We have measured heart rate, blood pressure, pulsus paradoxus, and cardiac output $(\dot{Q})$ in a group of children at the time of admission to hospital for treatment of severe acute asthma. These measurements have been related to peak expiratory flow rate (PEF) and arterial blood gas measurements. The changes which

Address for reprint requests: Dr AT Edmunds, Department of Child Health, Royal Hospital for Sick Children, St Michael's Hill, Bristol. occurred during the first two hours of treatment with aminophylline and a selective $\beta_{2}$ stimulant salbutamol have also been measured to assess the comparative effectiveness of these drugs in the treatment of severe acute asthma in children.

\section{Methods}

The study was approved by the ethics committee of the Royal Postgraduate Medical School, Hammersmith. Informed consent was obtained from the parents of all patients. Twenty-three patients were studied on 29 occasions at the time of admission to hospital for treatment of severe acute asthma. There were 12 boys and 11 girls. The mean age was 10 years (range 3 years 5 months to 13 years 10 months). Four children were studied twice and one on three occasions. All the patients had failed to respond to at least two adequate doses of bronchodilator at home and after clinical assessment were thought to require intravenous therapy.

Before treatment was started, the severity of the asthma was assessed by measurement of PEF and arterial blood gases. Peak expiratory flow rate was measured as the best of three attempts using a Wright's peak flow meter calibrated from 0-200 litres per minute. Arterial blood gases were measured on 
blood samples obtained from the radial artery under local anaesthetic. These measurements were correlated with heart rate, blood pressure, pulsus paradoxus, stroke volume, and $\dot{Q}$. Heart rate was calculated from the electrocardiogram recorded during measurement of cardiac output. Blood pressure was measured by auscultation of the Korotkoff sounds using a cuff covering at least twothirds of the upper arm. Pulsus paradoxus was measured using the same cuff. Cuff pressure was recorded on a $U / V$ recorder via a transducer and amplifier, together with a simultaneous recording of the Korotkoff sounds from a microphone placed over the brachial artery. The phase of respiration was recorded by an observer pressing a marker during each inspiration. The transducer was calibrated before and after each study using a mercury manometer. Pulsus paradoxus was taken as the difference between cuff pressure when the Korotkoff sounds first appeared and the highest pressure at which they were not interrupted during inspiration. Stroke volume and cardiac output were measured by transthoracic electrical impedance cardiography as described by Kubicek et $a^{9}$ and modified by Costeloe $e t$ al $^{10}$ to allow measurements while patients were breathing freely. Stroke volume was calculated as the mean of 8-12 consecutive cardiac cycles, covering a complete respiratory cycle. Cardiac output was calculated by multiplying mean stroke volume by mean heart rate during the period of measurement.

Measurements of PEFR and all the cardiovascular parameters were repeated at 15-minute intervals throughout the first two hours of treatment with aminophylline and salbutamol, a selective $\beta_{2}$ stimulant, to assess their cardiovascular effects and to relate these to changes of airway function. All patients were given oxygen via a face mask if they would tolerate it. Parents were encouraged to stay with their children and to help with the administration of oxygen and salbutamol when this was given via a nebuliser. All children were given infusions of dextrose $4 \%$ /saline $0 \cdot 18 \%$ at rates from $70-120 \mathrm{ml}$ per $\mathrm{kg}$ per 24 hours according to clinical assessment of fluid requirements. All patients received intravenous hydrocortisone $2 \mathrm{mg}$ per $\mathrm{kg}$ as a bolus followed by a continuous infusion of $1 \mathrm{mg}$ per $\mathrm{kg}$ per hour. During the first hour patients were randomly allocated to receive aminophylline, nebulised salbutamol, intravenous salbutamol, or a combination of both these drugs (fig 1). Aminophylline was given as a bolus over five minutes followed by a continuous infusion. The bolus dose was increased from $4 \mathrm{mg}$ per $\mathrm{kg}$ for patients 1 to 6 , to $5 \mathrm{mg}$ per $\mathrm{kg}$ for patients 7 to 16 , and to $6 \mathrm{mg}$ per $\mathrm{kg}$ for patients 17 to 29 . The infusion dose was increased from $0.7 \mathrm{mg} \mathrm{per}$ $\mathrm{kg}$ per hour for patients 1 to 16 , to $0.9 \mathrm{mg}$ per $\mathrm{kg}$ per hour for patients 17 to 29 . These increases were made as the plasma theophylline concentrations measured at the end of each study were below the therapeutic range of 10 to $20 \mu \mathrm{g}$ per $\mathrm{ml}$ when the lower doses were used. Nebulised salbutamol was given as 2.5 $\mathrm{mg}(0.5 \mathrm{ml})$ of respirator solution diluted in $1.5 \mathrm{ml}$ of saline via a Wright's nebuliser driven by oxygen at a

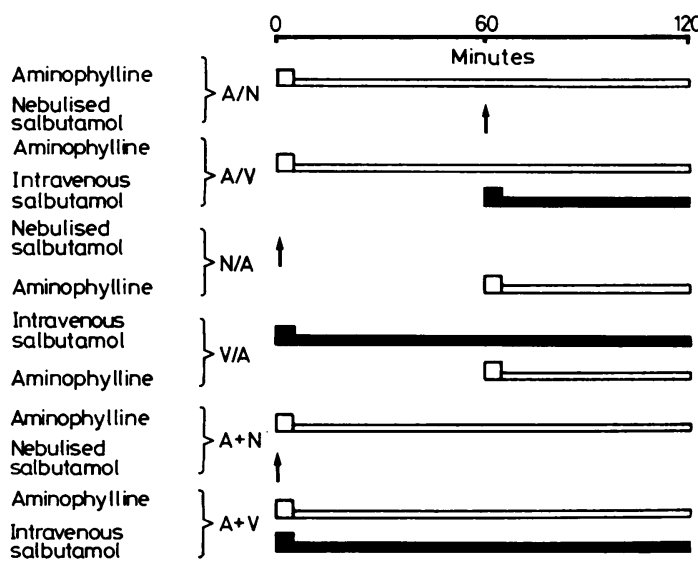

Fig 1 Treatment regimens used. $\square=$ Aminophylline bolus and infusion. $\mathbf{Q}=$ Salbutamol bolus and infusion. $\uparrow=$ Salbutamol given via Wright's nebuliser.

Table 1 Data recorded at the time of admission mean $\pm S D$

\begin{tabular}{|c|c|c|c|c|c|c|c|c|c|c|c|}
\hline $\begin{array}{l}\text { Treatment* } \\
\text { కroup }\end{array}$ & Number & Age (yr) & $\begin{array}{l}\text { Duration of } \\
\text { symptoms } \\
\text { (hours) }\end{array}$ & $\begin{array}{l}P E F+\% \\
\text { expected }\end{array}$ & $\begin{array}{l}\mathrm{PaO}_{2} \ddagger \\
\mathrm{KPa}_{2}\end{array}$ & $\begin{array}{l}\mathrm{PaCO}_{2} \ddagger \\
\mathrm{Pa}\end{array}$ & $\begin{array}{l}\text { Heart rate } \\
\text { (b/min) }\end{array}$ & $\begin{array}{l}\text { Pulsus } \\
\text { paradoxus } \\
(\mathrm{mmHg})\end{array}$ & $\begin{array}{l}\text { Surface area } \\
\left(m^{2}\right)\end{array}$ & $\begin{array}{l}\text { Stroke } \\
\text { volume } \\
\left(\mathrm{ml} / \mathrm{m}^{2}\right)\end{array}$ & $\begin{array}{l}\text { Cardiac } \\
\text { output } \\
\left(I / \mathrm{m}^{2} / \mathrm{min}\right)\end{array}$ \\
\hline $\begin{array}{l}\mathbf{A} / \mathbf{N} \\
\mathbf{A} / \mathbf{V} \\
\mathbf{N} / \mathbf{A} \\
\mathbf{V} / \mathbf{A} \\
\mathbf{A}+\mathbf{N} \\
\mathbf{A}+\mathbf{V} \\
\text { Mean }\end{array}$ & $\begin{array}{l}5 \\
5 \\
5 \\
5 \\
5 \\
4\end{array}$ & $\begin{array}{r}9 \pm 2 \\
10 \pm 2 \\
9 \pm 2 \\
10 \pm 4 \\
11 \pm 3 \\
8 \pm 4 \\
10 \pm 3\end{array}$ & $\begin{array}{l}30 \pm 17 \\
49 \pm 42 \\
31 \pm 11 \\
33 \pm 27 \\
27 \pm 10 \\
54 \pm 48 \\
37 \pm 26\end{array}$ & $\begin{array}{l}19 \pm 4 \\
21 \pm 5 \\
14 \pm 3 \\
18 \pm 6 \\
17 \pm 5 \\
19 \pm 4 \\
18 \pm 5\end{array}$ & $\begin{array}{l}8.5 \pm 0.9 \\
7.6 \pm 0.5 \\
8.0 \pm 0.4 \\
8 \cdot 1 \pm 0.7 \\
8.0 \pm 0.4 \\
8 \cdot 1 \pm 1.2 \\
8.0 \pm 0.7\end{array}$ & $\begin{array}{l}5.2 \pm 0.7 \\
4.9 \pm 1.3 \\
5.2 \pm 0.9 \\
5.2 \pm 0.8 \\
5.3 \pm 0.7 \\
5.5 \pm 1 \cdot 1 \\
5.2 \pm 0.9\end{array}$ & $\begin{array}{l}147 \pm 19 \\
138 \pm 18 \\
143 \pm 17 \\
126 \pm 11 \\
123 \pm 13 \\
146 \pm 24 \\
137 \pm 18\end{array}$ & $\begin{array}{l}24 \pm 6 \\
23 \pm 12 \\
26 \pm 10 \\
26 \pm 8 \\
29 \pm 8 \\
31 \pm 5 \\
26 \pm 8\end{array}$ & $\begin{array}{l}0.96 \pm 0.17 \\
1.03 \pm 0.16 \\
1.03 \pm 0.14 \\
1.08 \pm 0.23 \\
1.12 \pm 0.26 \\
0.93 \pm 0.29 \\
1.03 \pm 0.20\end{array}$ & $\begin{array}{l}39 \pm 8 \\
45 \pm 8 \\
39 \pm 8 \\
32 \pm 8 \\
34 \pm 10 \\
31 \pm 4 \\
37 \pm 9\end{array}$ & $\begin{array}{l}5.63 \pm 0.66 \\
6.25 \pm 1.54 \\
5.66 \pm 1.39 \\
4.00 \pm 0.82 \\
3.95 \pm 0.91 \\
4.46 \pm 0.81 \\
5.00 \pm 1.3\end{array}$ \\
\hline
\end{tabular}

See Fig. 1.

†PEF $\%$ expected $=$ PEF as $\%$ of expected normal predicted from height. ${ }^{13}$

$\$ 1 \mathrm{kPa}=7.5 \mathrm{mmHg}$. 
flow rate of eight litres per minute. Intravenous salbutamol was given as a bolus of $5 \mu \mathrm{g}$ per $\mathrm{kg}$ over five minutes, followed by a constant infusion of $5 \mu \mathrm{g}$ per $\mathrm{kg}$ per hour. When children were studied more than once the selection of treatment was repeated if the random allocation was the same as that on their previous admission. If children had received theophylline during the 12 hours before admission only treatment protocols involving the use of aminophylline during the first hour were permitted. The appropriate dose of aminophylline was calculated with the knowledge of the magnitude and timing of the previous dose. ${ }^{11}$

Correlations were calculated between cardiovascular changes and measures of severity of asthma. Analysis of variance and paired or unpaired $t$ tests were used to assess the responses to treatment and the differences between them. ${ }^{12}$

\section{Results}

The data recorded on admission to the study are shown in table 1. Peak expiratory flow was less than or equal to $25 \%$ of expected normal ${ }^{13}$ in all subjects in whom it was measured. In one very distressed and uncooperative child initial measurement was impossible but PEF recorded immediately after initial treatment was $13 \%$ of expected normal.

Arterial blood gas measurements were made in 26 admissions. Twenty-four samples were collected while the patients were breathing air and two while they were receiving oxygen via a face mask. Excluding the two patients receiving added oxygen, mean $\mathrm{PaO}_{2}$ was $8 \mathrm{kPa} \pm 0 \cdot 1 \mathrm{SE}$ and mean $\mathrm{PaCO}_{2}$ was $5 \cdot 2$ $\mathrm{kPa} \pm 0.2 \mathrm{SE}$ (Table 1). $\mathrm{PaCO}_{2}$ was greater than 5.5 $\mathrm{kPa}$ in $46 \%$ of patients. The reduction in PEF and the increase in pulsus paradoxus both correlated
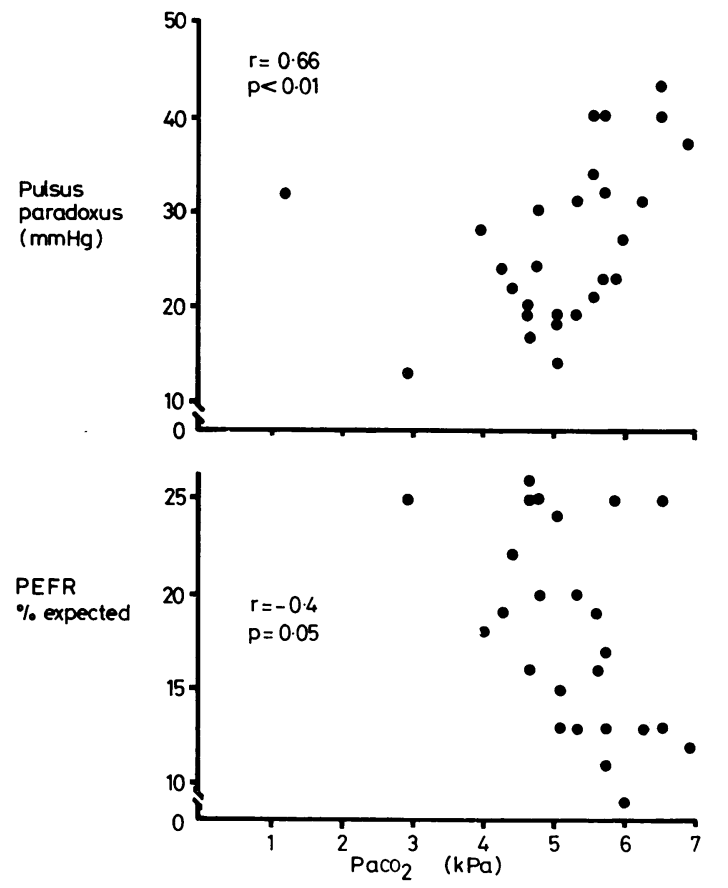

Fig 2 Linear regressions showing the correlations between pulsus paradoxus (top) PEF (bottom) and $\mathrm{PaCO}_{2}$ on admission.

significantly with $\mathrm{PaCO}_{2}$ (fig 2). Individual variability of both measurements prevented their use for accurate prediction of $\mathrm{PaCO}_{2}$, but pulsus paradoxus was always greater than $20 \mathrm{mmHg}$ when $\mathrm{PaCO}_{2}$ was greater than $5.5 \mathrm{kPa}$. $\mathrm{PaQ}_{2}$ did not show significant correlation with PEF or any of the cardiovascular measurements.

Mean stroke volume was $37 \mathrm{ml}$ per $\mathrm{m}^{2} \pm 1 \mathrm{SE}$ and

Table 2 Mean PEF as \% expected normal $\pm S E$ during treatment and mean serum theophylline $\pm S E$ after two hours for the six groups

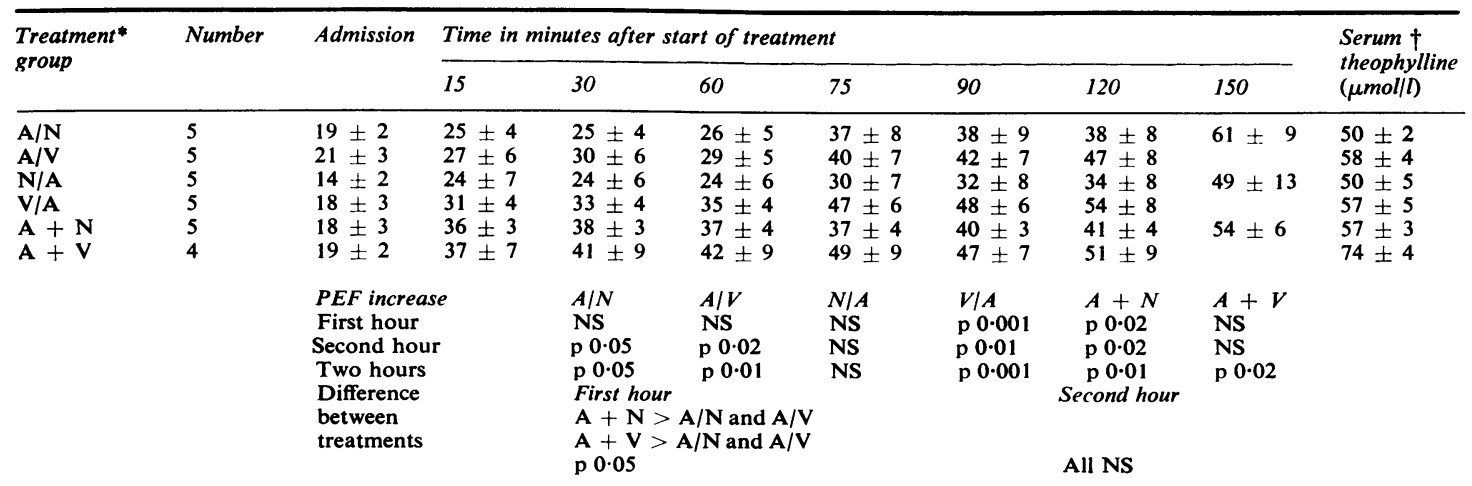

See fig. 1.

$\lceil 5.6 \mu \mathrm{mol}$ per litre $=1 \mu \mathrm{g}$ per $\mathrm{ml}$. 

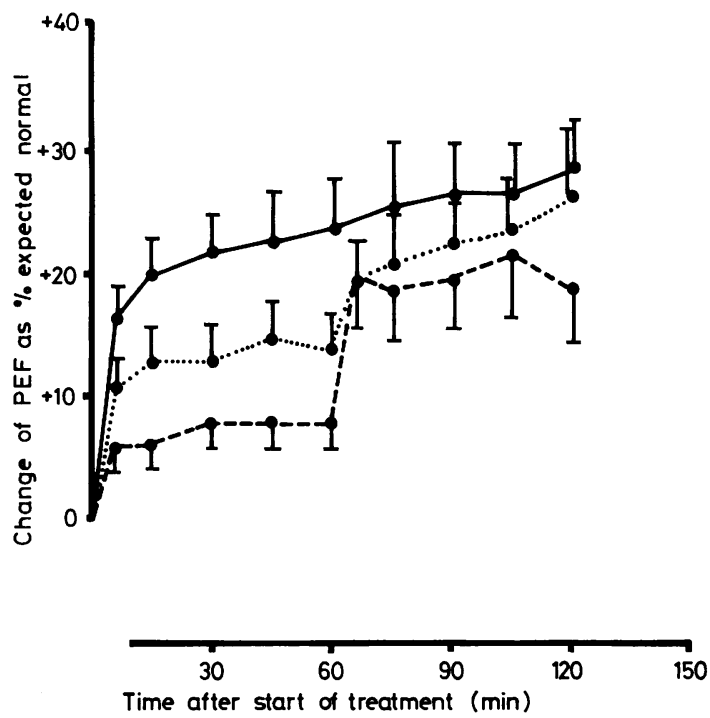

Fig 3 Mean increase in PEF $\pm S E$ as \% of expected normal; $-=$ patients receiving aminophylline and salbutamol throughout; ...... = patients receiving salbutamol during the first hour with addition of aminophylline during the second hour; -..-- = patients receiving aminophylline during the first hour with addition of salbutamol during the second hour.

mean cardiac output was 5.0 litres per $\mathrm{m}^{2}$ per minute $\pm 0.2 \mathrm{SE}$. These values represented $89 \% \pm 4$ $\mathrm{SE}$ and $131 \% \pm 4 \mathrm{SE}$ respectively of the values measured in the same children at rest during convalescence. Neither measurement correlated significantly with PEF, arterial blood gas measurement or pulsus paradoxus.

\section{RESPONSE TO THERAPY}

The mean concentrations of plasma theophylline achieved after two hours of treatment in the six groups of patients are shown in table 2. There were no significant differences between them. The mean theophylline concentration for patients 1 to 6 who received aminophylline as a bolus dose of $4 \mathrm{mg}$ per $\mathrm{kg}$ and an infusion of $0.7 \mathrm{mg}$ per $\mathrm{kg}$ per hour was 48 $\mu \mathrm{mol}$ per litre $\pm 7 \cdot 3 \mathrm{SE}(8.5 \mu \mathrm{g}$ per $\mathrm{ml} \pm 1.3 \mathrm{SE})$. The higher loading dose of $6 \mathrm{mg}$ per $\mathrm{kg}$ with a constant infusion of $0.9 \mathrm{mg}$ per $\mathrm{kg}$ per hour gave a mean plasma theophylline concentration of $62 \mu \mathrm{mol}$ per litre $\pm 5.6 \mathrm{SE}(11 \mu \mathrm{g}$ per $\mathrm{ml} \pm 1 \mathrm{SE})$ after two hours.

The changes in PEF after treatment are also shown in table 2 and fig 3. The mean PEF increased from $18 \% \pm 1 \mathrm{SE}$ of expected normal on admission to $44 \% \pm 2 \mathrm{SE}$ during the two hours studied $(p<0.001)$. There were significant increases in PEF recorded for all groups except group N/A (table 2).
There was considerable individual variation within the groups, but the increase of PEF during the first hour after administration of aminophylline together with salbutamol by nebuliser or intravenously $(A+N$ and $\mathbf{A}+V)$ was significantly greater than that after aminophylline alone (A/N and $A / V)$ $(p<0.01)$. It was also apparently greater than the mean increase after salbutamol alone, but the difference was not statistically significant. The route of administration of salbutamol did not affect the increase in PEF observed. After two hours the mean value was higher for patients who had received intravenous salbutamol and aminophylline, compared with those who had received nebulised salbutamol and aminophylline, but the difference was not significant. The apparent difference may have been dose-related, since a further increase in PEF was noted among 12 patients who were observed for a further half hour after receiving a second dose of nebulised salbutamol (table 2).

Patients given aminophylline and nebulised salbutamol showed a significant fall of systolic BP during the first hour $(\mathrm{p}<0.002)$, while diastolic pressure remained unchanged. Both systolic and diastolic BPshowed a trend downwards after intravenous salbutamol alone and together with aminophylline, but the changes were not significant. Pulsus paradoxus showed a significant decline in all patients (fig 4 (after 15 minutes and after two hours) $p<$ 0.001 ).

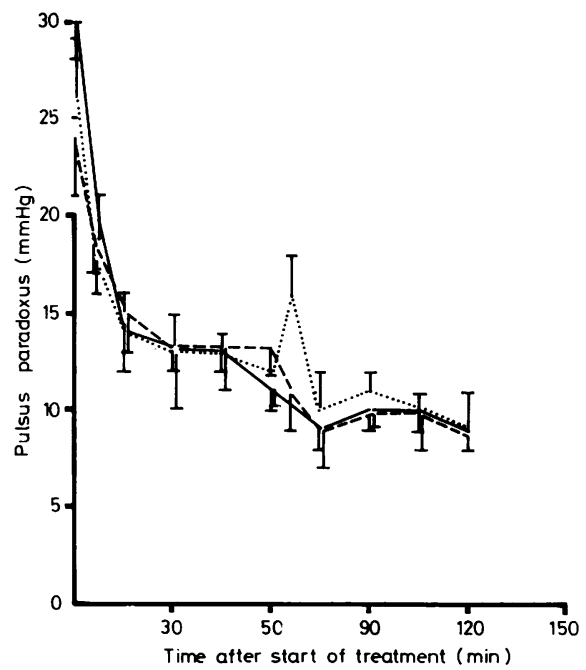

Fig 4 Mean pulsus paradoxus in $\mathrm{mmHg} \pm S E ;-=$ patients receiving salbutamol and aminophylline throughout $;. . . . .=$ patients receiving salbutamol during the first hour with addition of aminophylline during the second hour; ..... = patients receiving aminophylline during the first hour with addition of salbutamol during the second hour. 
Heart rate of patients receiving aminophylline and nebulised salbutamol separately and in combination steadily slowed from $138 \pm 3 \mathrm{SE}$ at the time of admission to $122 \pm 3$ SE beats per minute during two hours of treatment $(p<0.001)$. There was no further change of mean heart rate among the 12 patients given a second dose of nebulised salbutamol after two hours. In contrast the mean heart rate of 14 patients given intravenous salbutamol alone and together with aminophylline (groups A/V, V/A and $A+$ V) did not fall during treatment. After two hours their mean heart rate remained significantly higher than that of patients receiving nebulised salbutamol and aminophylline (fig $5 \mathrm{p}<0.001$ ). Changes of heart rate among these 14 patients did not reach statistical significance, but large transient increases did occur in some individuals. Three of four patients who received aminophylline and intravenous salbutamol together (group $\mathbf{A}+\mathrm{V}$ ) had heart rates above 190 beats per minute for 15 minutes after the bolus doses had been given.

There was no significant overall change of stroke volume or cardiac output in any of the six treatment groups (table 3 ). There were marked inter-subject differences in the responses observed. Change of cardiac output was more closely correlated with changes in stroke volume $(r=0.81, p<0.001)$ than with change of heart rate $(r=0.43, p<0.001)$. Nebulised salbutamol and aminophylline caused little change, while bolus injection of intravenous salbutamol alone and together with aminophylline was followed by change of cardiac output ranging from $-23 \%$ to $+100 \%$ of the admission value after one hour. After two hours when steady-state drug levels would have been achieved, stroke volume and cardiac output were no different among patients who had received intravenous salbutamol and aminophylline compared with those who had received nebulised salbutamol and aminophylline.

\section{Discussion}

Impedance cardiography is a rapid simple noninvasive method for measurement of cardiac output,
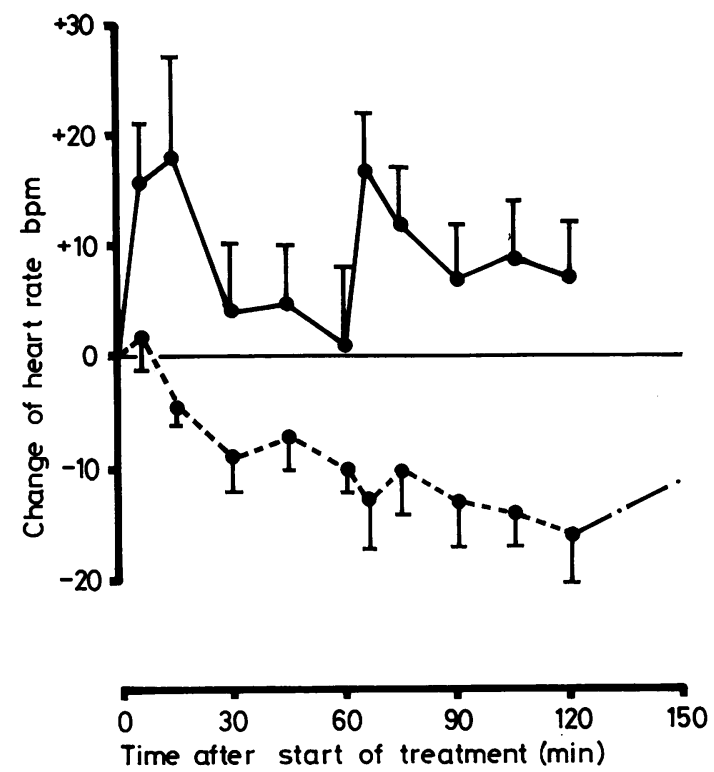

Fig 5 Mean change of heart rate in beats per minute $\pm S E ;-\ldots-E_{-}$patients who received nebulised salbutamol and aminophylline; $-1=$ patients who received intravenous salbutamol and aminophylline; $-\cdots \cdot-12$ patients given a second dose of nebulised salbutamol after two hours.

which can be used during severe acute asthma, and causes minimal interference with treatment. In normal subjects the Minnesota impedance cardiograph as described by Kubicek et $a l^{9}$ has given results for measurement of $\mathbf{Q}$ comparable with those derived by other standard techniques. ${ }^{9} 1014-20$ Modification of the method during a study of free breathing neonates gave values of $\dot{Q}$ which correlated well with simultaneous measurement of effective pulmonary flow $\left(r=0.79-0.93\right.$ dependent on haematocrit). ${ }^{10} \mathrm{Com}-$ parison with simultaneous measurements by the indirect Fick $\mathrm{CO}_{2}$ rebreathing method in normal subjects at rest, during exercise, and breathing against an expiratory resistance in our laboratory has confirmed the accuracy of this method $(r=0.96$,

Table 3 Mean change of stroke volume and cardiac output $\pm S E$ for the six groups during treatment

\begin{tabular}{|c|c|c|c|c|c|c|c|c|c|c|c|}
\hline \multirow{3}{*}{$\begin{array}{l}\text { Treatment* } \\
\text { group }\end{array}$} & \multirow{3}{*}{ Number } & \multicolumn{10}{|c|}{ Time in minutes after start of treatment } \\
\hline & & \multicolumn{5}{|c|}{ Stroke volume $\left(\mathrm{ml} / \mathrm{m}^{2}\right)$} & \multicolumn{5}{|c|}{ Cardiac output $\left(\mathrm{l} / \mathrm{m}^{2} / \mathrm{min}\right)$} \\
\hline & & 15 & 60 & 75 & 120 & 150 & 15 & 60 & 75 & 120 & 150 \\
\hline $\begin{array}{l}\mathbf{A} / \mathbf{N} \\
\mathbf{A} / \mathbf{V} \\
\mathbf{N} / \mathbf{A} \\
\mathbf{V} / \mathbf{A} \\
\mathbf{A}+\mathbf{N} \\
\mathbf{A}+\mathbf{V}\end{array}$ & $\begin{array}{l}5 \\
5 \\
5 \\
5 \\
5 \\
4\end{array}$ & $\begin{array}{r}-3 \pm 4 \\
-1 \pm 3 \\
2 \pm 3 \\
7 \pm 5 \\
1 \pm 4 \\
5 \pm 6\end{array}$ & $\begin{array}{r}-4 \pm 3 \\
-6 \pm 2 \\
5 \pm 3 \\
4 \pm 4 \\
-2 \pm 4 \\
9 \pm 3\end{array}$ & $\begin{array}{r}-3 \pm 5 \\
1 \pm 1 \\
2 \pm 2 \\
3 \pm 6 \\
3 \pm 7 \\
5 \pm 4\end{array}$ & $\begin{array}{r}-4 \pm 5 \\
-5 \pm 1 \\
4 \pm 3 \\
4 \pm 4 \\
4 \pm 5 \\
2 \pm 2\end{array}$ & $\begin{array}{r}-7 \pm 6 \\
5 \pm 3 \\
3 \pm 5\end{array}$ & $\begin{array}{r}-1.1 \pm 0.3 \\
-0.3 \pm 0.3 \\
-0.1 \pm 0.2 \\
1.2 \pm 0.8 \\
0.9 \pm 0.5 \\
2.0 \pm 0.7\end{array}$ & $\begin{array}{r}-1.1 \pm 0.3 \\
-1.0 \pm 0.3 \\
0.2 \pm 0.3 \\
0.6 \pm 0.4 \\
-0.3 \pm 0.4 \\
1.3 \pm 0.7\end{array}$ & $\begin{array}{r}-0.8 \pm 0.4 \\
0.7 \pm 0.2 \\
0.2 \pm 0.3 \\
1.2 \pm 1.0 \\
0.0 \pm 0.5 \\
1.0 \pm 1.1\end{array}$ & $\begin{array}{r}-1.2 \pm 0.4 \\
-0.3 \pm 0.2 \\
-0.1 \pm 0.3 \\
0.8 \pm 0.7 \\
-0.2 \pm 0.5 \\
0.5 \pm 0.6\end{array}$ & 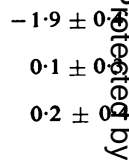 \\
\hline
\end{tabular}


unpublished). Expected values of $Q$ at rest vary with age, ${ }^{21} 22$ and the mean resting $Q$ at $4.01 / \mathrm{m}^{2} / \mathrm{min} \pm 0 \cdot 1$ SE measured during convalescence in our patients compares well with the expected values. Increased $\mathbf{Q}$ during moderately severe asthma appropriate for the measured increase in oxygen uptake, has previously been reported. ${ }^{8}$ Our results confirm that among children with severe acute asthma $Q$ was also increased to $131 \% \pm 4 \mathrm{SE}$ of the resting convalescent value. There was no correlation between $Q$ and PEF, pulsus paradoxus, or arterial blood gas measurements. The results did not suggest any general reduction of $\mathbf{Q}$ among patients with severe asthma.

There is no single bedside measurement which always predicts the severity of acute asthma. Clinical score, PEF, FEV ${ }_{1}$, heart rate have all shown poor correlation with measurements of arterial hypoxaemia. ${ }^{357}$ However, several studies have reported that pulsus paradoxus is a useful index in most patients. $^{357}$ Our results gave a significant correlation between pulsus paradoxus and $\mathrm{PaCO}_{2}$. It was the best single indicator of hypercapnia. All patients with $\mathrm{PaCO}_{2}$ greater than $5.5 \mathrm{kPa}$ had a paradox of more than $20 \mathrm{mmHg}$. The rapid fall of pulsus paradoxus seen in all treatment groups demonstrates that it is also a sensitive clinical indicator of improvement during treatment.

There are no published dose-response curves for the effect of salbutamol on airway function in children, but for convalescent adult asthmatic patients no further significant increase in PEF, FEV or FVC has been demonstrated after doses greater than $4.6 \mu \mathrm{g} / \mathrm{kg}$ bolus and $4 \mu \mathrm{g} / \mathrm{kg} / \mathrm{h}$ infusion. ${ }^{23} 24$ Therefore a bolus dose of $5 \mu \mathrm{g} / \mathrm{kg}$ and an infusion dose of $5 \mu \mathrm{g} / \mathrm{kg} / \mathrm{h}$ was chosen for this study. Nebulised salbutamol was given in a dose of $2.5 \mathrm{mg}$ since preliminary observation suggested larger doses gave no extra therapeutic benefit and doses of 5,10, and $20 \mathrm{mg}$ were all reported to cause similar increases in PEF in convalescent adults. ${ }^{25}$ The extra increase in PEF recorded in 12 patients given a second dose of nebulised salbutamol after two hours makes it likely that a larger initial dose would have been more effective. It is also possible that the initial bronchodilation enabled the second dose to penetrate further within the lungs. The finding of similar increases in PEF after both nebulised salbutamol and intravenous salbutamol is in contrast to previous reports $^{26}$ that the intravenous route is more effective during treatment of severe acute asthma in adults. This together with the very rapid clinical improvement of the patients in this study suggests that children with asthma may be more responsive to the bronchodilator effects of $\beta$ stimulants and phosphodiesterase inhibitors than most adults.

The cardiovascular effects of aminophylline and salbutamol were relatively small. There was a significant fall in heart rate after administration of aminophylline and nebulised salbutamol, but changes of stroke volume and cardiac output were not significant. Some patients given intravenous salbutamol showed large transient changes in heart rate, stroke volume, and $\dot{Q}$ which may have been avoided if the bolus doses had been given more slowly.

In conclusion this study has demonstrated that during untreated severe acute asthma in children cardiac output was slightly increased above resting levels. Aminophylline and salbutamol were safe and effective in the treatment of such children. Their bronchodilator effect was greater when they were given together. Inhalation of salbutamol via a nebuliser is recommended in preference to intravenous injection since, in the doses used, similar improvement in airway function was achieved with little or no cardiovascular disturbance.

\section{References}

${ }^{1}$ Simpson H, Forfar JO, Grubb DJ. Arterial blood gas tensions and $\mathrm{pH}$ in acute asthma in childhood. $\mathrm{Br}$ Med J 1968;iii:460-4.

${ }^{2}$ Rees HA, Millar JS, Donald KW. A study of the clinical course and arterial blood gas tensions of patients in status asthmaticus. $Q J$ Med 1968;37:541-56.

${ }^{3}$ Rebuck AS, Read J. Assessment and management of severe asthma. Am J Med $1971 ; 51: 788-98$.

${ }^{4}$ McKenzie SA, Edmunds AT, Godfrey S. Status asthmaticus in children: a one year study. Arch Dis Child 1979;54: 581-6.

${ }^{5}$ Knowles GK, Clark TJH. Pulsus paradoxus as a valuable sign indicating severity of asthma. Lancet 1973 ;ii:1356-9.

6 Rebuck AS, Tolmarken JL. Pulsus paradoxus in asthmatic children. Can Med Assoc J 1975;112:710-1.

${ }^{7}$ Galant SP, Groncy CF, Shaw KC. The value of pulsus paradoxus in assessing the child with status asthmaticus. Pediatrics 1978;61:46-51.

${ }^{8}$ Permutt S. Some physiological aspects of asthma: bronchomuscular contraction and airways calibre. In: Porter R, Birch J, eds. Identification of Asthma. Ciba Foundation Study Group No 38. London: Churchill, 1971:63-85.

${ }^{9}$ Kubicek WG, Karnegis JN, Patterson RP, Witsoe DA, Mattson RH. Development and evaluation of an impedance cardiac output system. Aerospace Med 1966; 37:1208-12.

${ }^{10}$ Costeloe K, Stocks J, Godfrey S, Mohapatra SN, Hill DW. Cardiac output in the neonatal period using impedance cardiography. Pediatr Res 1977;11:1171-6.

${ }^{11}$ McKenzie SA, Edmunds AT, Baillie E, Meek JH. Clinical applications of serum theophylline measurement by high pressure liquid chromatography. Arch Dis Child 1978; 53:322-5.

${ }^{12}$ Cochran WG, Cox GM. Experimental designs. Second edition. New York: Waley, 1957.

${ }^{13}$ Godfrey S, Kamburoff PL, Nairn JR. Spirometry, lung volumes and airway resistance in normal children aged 5-18 years. Br J Dis Chest 1970;64:15-24.

${ }^{14}$ Harley A, Greenfield JC. Determination of cardiac output in man by means of impedance plethysmography. Aerospace Med 1968;39:248-52. 
15 Judy WV, Langley FM, McCowen KD, Stinnett DM, Baker LE, Johnson PC. Comparative evaluation of the thoracic impedance and isotope dilution methods for measuring cardiac output. Aerospace Med 1969;40: 532-6.

${ }^{16}$ Kinnen E. Cardiac output from transthoracic impedance variations. Ann N Y Acad Sci 1970;170:747-56.

17 Lababidi Z, Ehmke DA, Durnin RE, Leaverton PE, Laver RM. Evaluation of impedance cardiac output in children. Pediatrics 1971;47:870-9.

${ }^{18}$ Baker LE, Judy WV, Geddes LE, Langley FM, Hill DW. Measurement of cardiac output by means of electrical impedance. Cardiovasc Res Cent Bull 1971;9:135-45.

19 Hill DW, Thompson FD. The importance of blood resistivity in the measurement of cardiac output by the thoracic impedance method. Med Biol Eng 1975;13: 187-90.

20 Denniston JC, Maher JT, Reeves JT, Cruz JC, Cymerman A, Grover RF. Measurement of cardiac output by electrical impedance at rest and during exercise. $J$ Appl Physiol 1976;40:91-5.

${ }^{21}$ Brotmacher L, Flemming P. Cardiac output and vascular pressures in 10 normal children and adolescents. Guys Hosp Rep 1957;106:268-72.

${ }^{22}$ Brandfonbrener M, Landowne M, Shock NW. Changes in cardiac output with age. Circulation 1955;12:557-66.

${ }^{23}$ Spiro SG, Johnson AJ, May CS, Paterson JW. Effect of intravenous injection of salbutamol in asthma. $\mathrm{Br} J$ Clin Pharmacol 1975;2:495-501.

${ }^{24}$ May CS, Paterson JW, Spiro SG, Johnson AJ. Intravenous infusion of salbutamol in the treatment of asthma. Br J Clin Pharmacol 1975 ;2:503-8.

${ }^{25}$ Choo-Kang YFJ, Parker SS, Grant IWB. Response of asthmatics to isoprenaline and salbutamol aerosols administered by intermittent positive pressure ventilation. Br Med J 1970;iv:465-8.

${ }^{26}$ Williams S, Seaton A. Intravenous or inhaled salbutamol in severe acute asthma? Thorax 1977;32:555-8. 